(C) Yemchenko Ya.O., Ishcheikin K.Ye., Kaidashev I.P.

UDC 616.517-056.5:613.1/.25-056.52

DOI https://doi.org/10.31718/mep.2021.25.1-2.02

\title{
CIRCADIAN RHYTHM AND INDICATORS OF SYSTEMIC INFLAMMATION IN PATIENTS WITH PSORIASIS AND CONCOMITANT ALIMENTARY OBESITY*
}

\author{
Yemchenko Ya.O., Ishcheikin K.Ye., Kaidashev I.P. \\ Ukrainian Medical Stomatological Academy (Poltava)
}

The study was a part of the research No. 0120 U101166 "The study of the pathogenetic role of the circadian molecular clock in the development of metabolic diseases and systemic inflammation and the development of treatment methods aimed at these processes" funded by the Ministry of Public Health of Ukraine.

Псоріаз - один із найбільш поширених дерматозів, яким за даними світової статистики воОз страждають від 2\% до 4\% населення нашої планети. Збільшення випадків коморбідності псоріазу та ожиріння, що спостерігаються останнім часом, призводять до тяжких, атипових, інвалідизуючих та резистентних до терапії форм дерматозу, значно погіршують якість життя пацієнтів, знижують працездатність та соціальну активність хворих, що визначає не тільки медичну, але й соціальну значимість проблеми. Існує теоретичне обгрунтування можливої ролі порушень циркадного ритму, яке проявляється зміною харчової поведінки, зменшенням тривалості сну та індивідуального хронотипу хворих в розвитку ожиріння, хронічного запалення низької інтенсивностісті та деяких хронічних аутоімунних захворювань таких, як псоріаз. Однак, дане питання залишається недостатньо вивченим $i$ доведеним. Тому, метою нашого дослідження стало виявлення кореляційної залежності між циркадним ритмом за показниками змін хронотипу працездатності людини та показниками сиситемного запалення у хворих на розповсюжжений псоріаз з супутнім аліментарним ожирінням. Результати кореляційного аналізу показали високу негативну кореляційну залежність між хронотипом працездатності хворих та рівнем ІЛ-33 та середню негативну кореляційна залежність між рівнем IЛ-6, СРБ та хронотипом працездатності хворих. Тож, зміни циркадного ритму на вечірній тип хронотипу працездатності людини можуть сприяти підвищенню рівня показників системного запалення у хворих на розповсюджений вульгарний псоріаз з супутнім аліментарним ожирінням. Отже, подальше більш поглиблене вивчення взаємозв'язку показників системного запалення та змін циркадного ритму у хворих на розповсюджений вульгарний псоріаз з супутнім аліментарним ожирінням є перспективним і вкрай необхідним для розробки науково-обгрунтованих принципів ранньої профілактики та своєчасної корекції даних коморбідностей.

Ключові слова: псоріаз, ожиріння, показники системного запалення, порушення циркадного ритму.

Psoriasis is one of the most common dermatoses, affecting from $2 \%$ to $4 \%$ of the world's population, according to the statistics from WHO. The recent increase in the incidence of comorbid psoriasis and obesity leads to severe, atypical, disabling, and treatment-resistant forms of dermatosis, which significantly impair the quality of life of patients, reduce the efficiency and social activity of patients, thus acquiring not only a medical but also a social significance. There is a theoretical justification for a possible role of circadian rhythm disorders, manifested by changes in eating behavior, reduced sleep duration, and individual chronotype of patients in the development of obesity, chronic low-intensity inflammation, and some chronic autoimmune diseases such as psoriasis. However, this issue remains understudied and insufficiently substantiated. Therefore, the aim of our research was to identify the correlation between the circadian rhythm in terms of changes in the chronotype of human working capacity and indicators of systemic inflammation in patients with extensive psoriasis and concomitant alimentary obesity. The results of correlation analysis showed a high negative correlation between the working capacity chronotype in patients and the level of IL-33, as well as a medium negative correlation between the working capacity chronotype in patients and the level of IL-6 and CRP. Therefore, changes in the circadian rhythm to the evening type of human working capacity chronotype may increase the level of systemic inflammation in patients with extensive vulgar psoriasis and concomitant alimentary obesity. Thus, further in-depth study of the relationship between systemic inflammation and circadian rhythm changes in patients with extensive vulgar psoriasis and concomitant alimentary obesity is promising and essential for the development of scientifically substantiated principles for early prevention and timely correction of these comorbidities.

Key words: psoriasis, obesity, indicators of systemic inflammation, circadian rhythm disorders.

Psoriasis is one of the most common dermatoses, affecting from $2 \%$ to $4 \%$ of the world's population, according to the statistics from WHO [1]. The recent increase in the incidence of comorbid psoriasis and obesity leads to severe, atypical, disabling, and treatment-resistant forms of dermatosis, which significantly impair the quality of life of patients, reduce the efficiency and social activity of patients, thus acquiring not only a medical but also a social significance. At the present stage, the possible causes of obesity include epigenetic changes, the impact of endo- crine disruptors, eating disorders, circulatory disorders of the body, and reduced sleep duration [2]. The research literature increasingly discusses the identical pathogenetic mechanisms of inflammatory processes in psoriasis, obesity, and circadian rhythm disorders, which form a vicious circle at the level of the immune system [3]. The researchers found that under conditions of active inflammation in the body, the expression of a genetic factor known as NF-kappa beta (NF-KB) increases excessively. $N F-k B$ is a catalyst for a series of chain reactions that

*To cite this English version: Yemchenko Ya.O., Ishcheikin K.Ye., Kaidashev I.P. Circadian rhythm and indicators of systemic inflammation in patients with psoriasis and concomitant alimentary obesity. // The Medical and ecological problems. - 2021. - Vol 25, № 1-2. - P. 7-11. 
form a holistic picture of the pathogenesis of pain and tissue destruction caused by inflammation. The same trigger, according to researchers, controls the periodicity of circadian rhythms in the body [4]. The main cells involved in the inflammatory process include mast cells. Mast cell division and activation are associated with circadian rhythms through the two main pathways: IgE / FceRIand IL-33 / ST2-mediated signaling. Moreover, there are persistent variations between clock genes and genes specific for mast cells [5]. Melatonin and histamine are the main neuromodulators involved in the regulation of circadian rhythms and inflammation. NF-KB interacts with the core clock genes and disrupts the production of proinflammatory cytokine mediators such as IL-6, IL-13, and TNF- $\alpha$. To date, no studies have evaluated the relationship between melatonin and histamine in terms of circadian oscillations in mast cells. However, the accumulated data suggest that the restoration of circadian rhythms in mast cells by targeting melatonin and histamine through NF-KB may be a promising therapeutic strategy for mast cell-mediated inflammatory diseases [6].

Therefore, further in-depth study of the relationship between systemic inflammation and circadian rhythm changes in patients with psoriasis and concomitant alimentary obesity is promising and essential for the development of scientifically substantiated principles for early prevention and timely correction of these comorbidities.

The aim of the research was to identify the correlation between the circadian rhythm in terms of changes in the chronotype of human working capacity and indicators of systemic inflammation in patients with extensive psoriasis and concomitant alimentary obesity.

\section{Materials and methods}

The PASI (Psoriatic Area and Severity Index) was used to assess the severity of psoriasis [7].

To assess the severity of alimentary obesity, body mass index (BMI) was calculated [8]. Subjects with a $\mathrm{BMI}$ of $30-40 \mathrm{~kg} / \mathrm{m}^{2}$ were included in the study.

To determine the chronotype of human working capacity, we used the international Horne and Östberg test in the modification by S.I. Stepanova (1986) [9].

To assess the severity of systemic inflammation, we determined the concentration of high-sensitivity Creactive protein (hs-CRP), interleukin-33 (IL-33), and interleukin-6 (IL-6) in the serum of patients by enzymelinked immunosorbent assay on a multichannel photometer "STATFAX-303" (USA). To quantify indicators, we used the commercial test systems "interleukin-6-ELISABEST" (Russia), "CRP-ELISA-BEST" (Russia), "Human IL-33 ELISA Kit User Guide" "eBioscience ${ }^{\mathrm{TM}} /$ Affymetrix" (USA) according to the recommended methods. Statistical processing of the obtained results was performed using the Statistica 7.0 software. The difference was considered significant at $p<0.05$. A pairwise factor correlation analysis was performed by calculating the Pearson correlation coefficient ( $r$ ).

\section{Results and discussion}

We examined 80 patients with the diagnosis of extensive vulgar psoriasis, progressive stage, moderate severity with concomitant grade I-II obesity, 51 (64\%) men and 29 (36\%) women aged from 35 to 65 years. The duration of the disease was from 3 to 36 years. Psoriatic lesions were extensive in all patients. From the anamnesis of the disease, $28(35 \%)$ patients had the autumn-winter type of psoriasis, $2(2.5 \%)$ patients had the spring-summer type, and $50(62.5 \%)$ patients had the undifferentiated type. When determining the number of recurrences of psoriasis per year, it was found that recurrence of the disease was observed once a year in $2(2.5 \%)$ patients, 2 times a year - in $11(14 \%)$ patients, 3 times a year - in $46(57.5 \%)$ patients and 4 times a year - in $21(26 \%)$ patients. Psoriasis was diagnosed according to the protocol (order No.312 as of 8.05.2009).

When examining patients from the study group and calculating the BMI in accordance with the classification of obesity, we found that 29 patients had grade I obesity $\left(\mathrm{BMl} \pm 34.04 \mathrm{~kg} / \mathrm{m}^{2}\right)$, and 51 patients $(\mathrm{BMl} \pm 38.15 \mathrm{~kg} /$ $\left.\mathrm{m}^{2}\right)$ had grade II obesity.

In the study of systemic inflammation, the average group values of hs-CRP, IL-33, and IL- 6 were calculated. When analyzing the obtained results, we found that all patients had an increase in hs-CRP $(13.99 \pm 2.98 \mathrm{IU} / \mathrm{l})$, 79 patients had an increase in IL-33 $(73.69 \pm 7.5 \mathrm{pg} / \mathrm{ml})$, and 78 patients had an increase in IL-6 (13.01 \pm 1.54 $\mathrm{pg} / \mathrm{ml}$ ), indicating the presence of a systemic inflammatory process in all examined patients.

When determining the circadian rhythm, we analyzed the data from questionnaires to determine the chronotype of human working capacity by Horne and Östberg method in the modification by S.I. Stepanova. According to the results of the study, it was found that 27 patients had a weak evening chronotype of working capacity, 50 patients had a clear evening chronotype of working capacity, and 3 patients had an arrhythmic chronotype of working capacity. The average group index of the working capacity chronotype in patients was $40.6 \pm 10.2$ points. In turn, people with weak evening and clear evening chronotypes of working capacity belong to the category of "owls", whereas people with an arrhythmic chronotype of working capacity belong to the category of "pigeons".

In order to identify the relationship between the circadian rhythm and indicators of systemic inflammation in patients with extensive psoriasis and concomitant grade I-Il alimentary obesity, we conducted a correlation analysis between the chronotype of patients' working capacity and the level of systemic inflammation (IL-33, IL-6, and hs-CRP).

The results of the correlation analysis between the level of IL-33 and the chronotype of working capacity in patients showed a high negative correlation between the examined indicators $(R=-0.822476)$ (Fig. 1A).

The results of the correlation analysis between the level of IL-6 and the chronotype of working capacity in patients showed a medium negative correlation between the examined indicators $(R=-0.58775)$ (Fig. 1B).

The results of the correlation analysis between the level of hs-CRP and the chronotype of working capacity in patients showed a medium negative correlation between the examined indicators $(R=-0.652802)$ (Fig. 1C). 

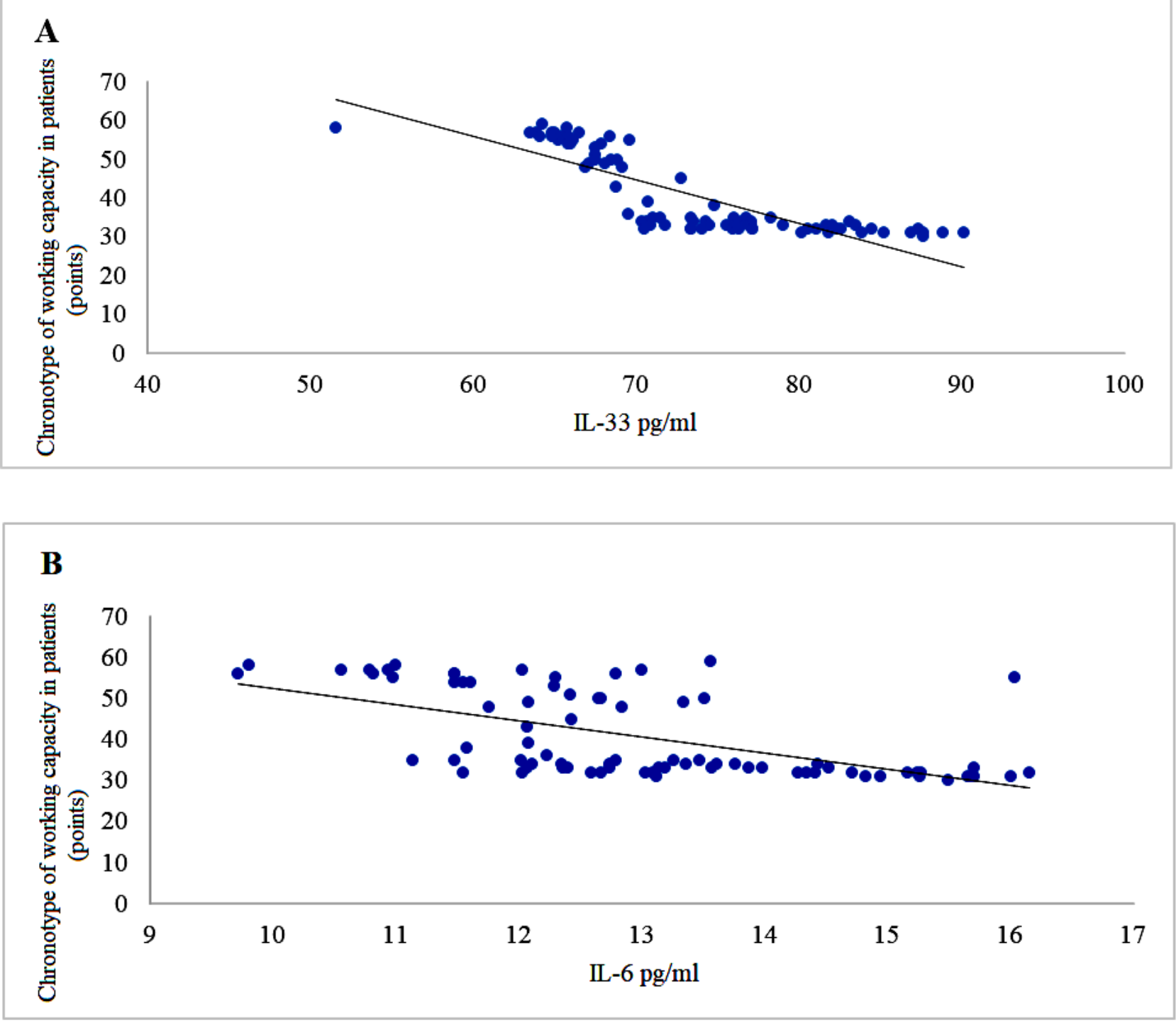

C

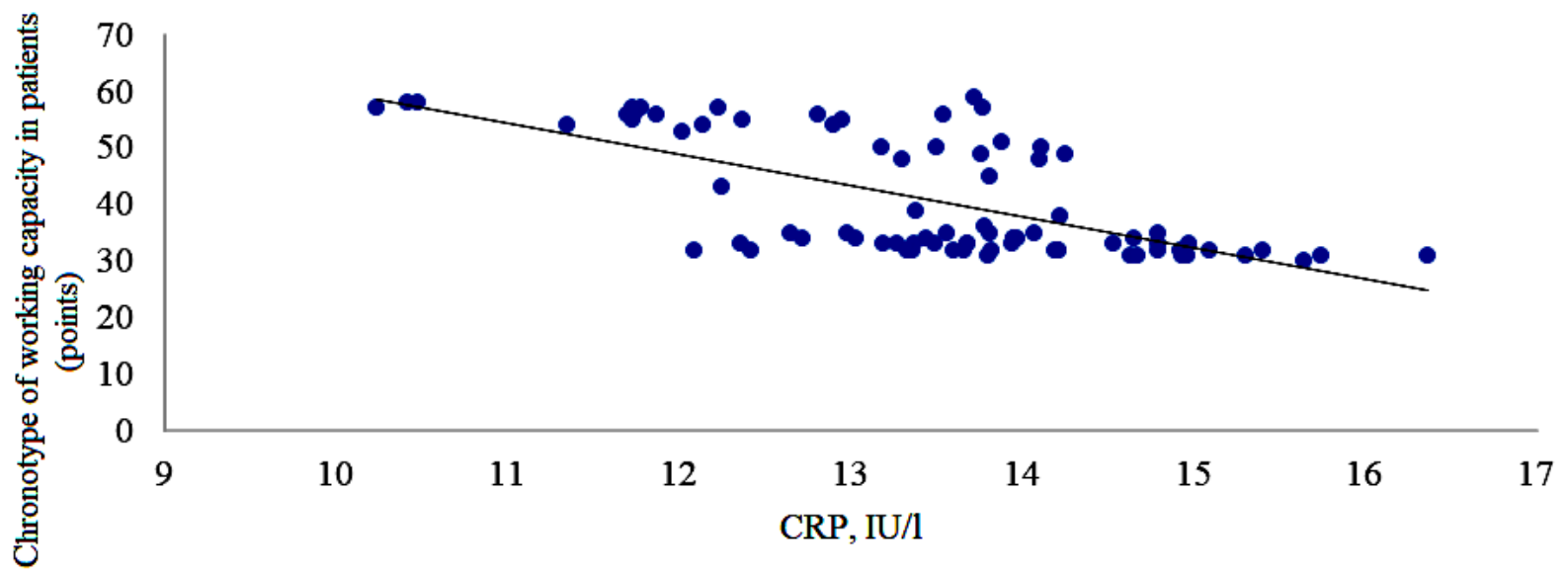

Figure 1. Correlation between the working capacity chronotype and indicators of systemic inflammation in patients with psoriasis with concomitant grade I-II alimentary obesity.

Correlation analysis between (A) the working capacity chronotype of patients and IL-33;

(B) the working capacity chronotype of patients and IL-6;
(C) the working capacity chronotype of patients and CRP. 
Analyzing the results of the obtained correlation analysis, we noted that the level of systemic inflammation in patients with psoriasis and concomitant alimentary obesity depends on changes in the circadian rhythm of the examined patients. The results of correlation analysis showed a high negative correlation between the chronotype of working capacity in patients and the level of IL-33, as well as a medium negative correlation between the chronotype of working capacity in patients and the levels of IL-6 and hs-CRP. Thus, the higher the level of systemic inflammation of the examined patients, the lower the chronotype of working capacity, which corresponds to more pronounced changes in the circadian rhythm by the "owl" type. Thus, patients with a pronounced evening type of the working capacity chronotype have higher rates of IL-33, IL-6, and hs-CRP. The results of our research coincide with the results of other studies. A study by Rongguo Yu. (2019) found that disorders of circadian clock gene expression were associated with an increased plasma level of inflammatory markers such as IL-6 and tumor necrosis factor (TNF) [10].

It is known that melatonin and histamine are the main mediators of inflammation involved in the regulation of circadian rhythms. Their secretion directly depends on patients' working capacity chronotype. Patients with psoriasis, concomitant alimentary obesity, and the "owl" type circadian rhythm disorders are characterized by the presence of constant stress, leading to an uncontrolled release of cortisol, which blocks the synthesis of diamine oxidase. It is known that diamine oxidase is an antagonist of histamine. Diamine oxidase causes the breakdown of histamine. With a decrease in the duration of sleep, characteristic for the "owl" chronotype at night, the synthesis of melatonin decreases, which is very important for the synthesis of diamine oxidase. Thus, a reduction in melatonin synthesis leads to a decrease in the synthesis of diamine oxidase, which causes an increase in histamine levels and contributes to histaminosis. Elevation of histamine level causes dilation of microcirculatory vessels, increases their permeability, contributing to inflammatory infiltration of tissues, which triggers an acute inflammatory response and enhances systemic inflammation $[11,12]$.

Thus, in a model of experimental arthritis, it was found that markers of inflammation are reduced during sleep at night. Subsequent researches have shown that active molecular clock and resident inflammatory cells, fibroblast-like synoviocytes, which are a possible source of rhythmic inflammatory signals, function in the inflamed tissues. Exposure of mice to constant lighting disrupted the clock in the peripheral tissues, decreasing the nocturnal suppression of local inflammation. Thus, the "biological clock" actively reduces the degree of inflammation during sleep at night [13].

Therefore, in recent years, sleep disorder is considered the cause of many chronic and autoimmune diseases, including obesity [14]. The main function of sleep, as a restorative process, allows the body to adapt to the changing conditions of the external and internal environment. However, many people, creating an artificial lighting environment at night, change their chronotypes, thereby reducing the time of natural sleep and decreasing its protective properties, which leads to the development of various pathological conditions [15].

Another study by the scientists from Northwestern University Feinberg School of Medicine, USA, showed that inflammation, which is a major factor in autoimmune imbalances, exerts a critical effect on the profile of biorhythms in the body, leading to the development of sleep disturbances and related disorders [16, 17].

The researchers also observed that the relationship that characterizes the line of interaction between inflammatory processes and biorhythm disorders in the body is associated not only with understanding how inflammation changes the mode of the brain activity and sleep-wake cycles, but also with the features of immunoregulation and functions of adipocytes [18].

In our study, a strong inverse interrelation between the working capacity chronotype and the level of IL-33 may be due to the fact that IL-33, having a dual function, can function not only as a proinflammatory cytokine but also as a signaling molecule for type I macrophages, which produce inflammatory cytokines, enhancing the inflammatory response. IL-33 expression is activated after proinflammatory stimulation, and its level correlates with the level of inflammation in the tissue. IL-33 is a cytokine that acts as a traditional cytokine by activating the ST2L receptor complex and as an intracellular nuclear factor with regulatory transcriptional properties. IL-33 increases the synthesis of IL- $6, \mathrm{IL}-13, \mathrm{IL}-1 \beta$, and TNF- $\alpha$. In a multicenter clinical study, the researchers found that IL33 is an inducer of IL-6 in mast cells [19, 20].

Therefore, further in-depth study of the relationship between systemic inflammation and circadian rhythm changes in patients with psoriasis and concomitant alimentary obesity is promising and essential for the development of scientifically substantiated principles for early prevention and timely correction of these comorbidities.

\section{Conclusions}

Changes in a person's circadian rhythm and chronotype to the evening type lead to an increase in systemic inflammation in patients with extensive psoriasis and concomitant alimentary obesity. Thus, lifestyle changes with an increased time for rest at night in patients with extensive psoriasis and concomitant alimentary obesity will reduce systemic inflammation and improve the course of these comorbidities. At the same time, systemic inflammation may be a target for drug effect in the therapeutic correction of circadian rhythm changes.

\section{References}

1. Yemchenko, J. A. Dependence of clinical and laboratory indicators of the level of systemic inflammation in patients with psoriasis of moderate severity with concomitant metabolic syndrome. Georgian Medical News. 2014; 11 (236):43-47.

2. Razina A.O., Achkasov E.E., Runenko S.D. Ozhirenie: sovremennyj vzglyad na problemu. Ozhirenie i metabolizm. 2016; 13, 1:3-8.

3. Kaidashev IP. Izmenenie obraza zhizni, narushenie energeticheskogo metabolizma i sistemnoe vospalenie kak faktory razvitiya boleznej civilizacii. [Change of lifestyle, energy metabolism disturbance and systemic inflammation as the evolution factors of civilization diseases] Ukrainskyi medychnyi chasopys. 2013; 5:103-108.

4. Hong H.-K., Maury E., Ramsey K.M. [et al.]. Requirement for NF-kB in maintenance of molecular and behavioral circadian rhythms in mice. Genes Dev 2018; 32:13671379.

5. Linh Pham, Leonardo Baiocchi, Lindsey Kennedy, Keisaku Sato. The interplay between mast cells, pineal gland, and circadian rhythm: Links between histamine, melatonin, and inflammatory mediators. Journal of pineal research. 2020; 70:128-135.

6. Rongguo Yu., Linlin Tian., Yi Ding., Yali Gao [at al]. Correlation between inflammatory markers and impaired cir- 
cadian clock gene expression in the 2 diabetes mellitus. Diabetes research and clinical practice. 2019; 2:85-93.

7. National Institutes of Health (NIH), National Heart, Lung, and Blood Institute (NHLBI). The practical guide: identification, evaluation, and treatment of overweight and obesity in adults. Bethesda: National Institutes of Health. 2000; NIH publication 00-4084.

8. Fredriksson, T., U. Pettersson. Severe psoriasis-oral therapy with a new retinoid. Dermatologica. 1978; 157(4):238-44.

9. Rehman A. Sleep/Wake homeostasis and sleep drive [Online]. Available from: http://snotvornoe.ru/sleep/biorhythms/about/\%E2\%80\%8

10. Komarov F.I., Rapoport S.I., Breus T.K., Chibisov S.M. Desinchronization of biological rhythms as a response to the influence of environmental factors. Klinicheskaya meditsina. 2017; 95(6):502-512.

11. Pudikov I.V. Narusheniya ritma «son-bodrstvovanie» pritransmeridiannyh pereletah (sindrom smeny chasovyh po-yasov) i ih korrekciya. Effektivnaya farmakoterapiya. Nevrologiya Specvypusk "Son i ego rasstrojstva - 6». 2018; 35:46-54

12. Hand LE, Hopwood TW, Dickson SH, Walker AL, Loudon AS, Ray DW, [et al.]. The circadian clock regulates inflammatory arthritis. J. Faseb 2016; 30(11):3759-3770.

13. Colles SL, Dixon JB, O'Brien PE. Night eating syndrome and nocturnal snacking: association with obesity, binge eating and psychological distress. Int J Obes (Lond). 2017; 31:1722-1730.

14. Eckel RH, Depner CM, Perreault L, Markwald RR, Smith MR, McHill AW, [et al.]. Morning Circadian Misalignment during Short Sleep Duration Impacts Insulin Sensitivity. Curr Biol. 2015; 25(22):3004-3010.

15. Kaidashev I.P. Aktyvatsiia NF-kB pry metabolichnomu syndromi. [NF-kB activation as a molecular basis of pathological process by metabolic syndrome] Fiziolohichnyi zhurnal. 2012; 58(1):93-101.

16. Inflammation can lead to circadian sleep disorders: Nove technology turns inflammation on and off, affecting body clock in mice. Northwestern University. ScienceDaily. 2018; 31:128-135.

17. Kaidashev I.P. Rol' molekulyarnyh chasov cirkadiannyh ritmov $\vee$ patogeneze metabolicheskogo sindroma. [The role of the molecular clock of circadian rhythms in the pathogenesis of metabolic syndrome] Endocrinology. 2020; 25(2):158-170.

18. Yemchenko Ya. A., Ishcheykin K. F., Kaidashev, I. P Modern views of the immunopathogenesis of psoriasis disease. World of Medicine and Biology. 2018; 3 (65): 134139.

19. Liew FY, Girard JP, Turnquist HR. Interleukin-33 in health and disease. Nat Rev Immunol. 2016;16(11):676-689.

Матеріал надійшов до редакції 22.02.2021 